\title{
Effect of Thermo-Treatment on the Physical and Mechanical, Color, Fungal Durability of Wood of Tectona grandis and Gmelina arborea from Forest Plantations
}

\author{
Luis Diego MÉNDEZ-MEJÍAS ${ }^{1 *}$, Róger MOYA ${ }^{2}$ \\ ${ }^{1}$ Maestría en Ciencias Forestales, Instituto Tecnológico de Costa Rica, P.O. Box: 159-7050 Cartago-Costa Rica \\ ${ }^{2}$ Escuela de Ingeniería Forestal, Instituto Tecnológico de Costa Rica, P.O. Box: 159-7050 Cartago-Costa Rica \\ crossref http://dx.doi.org/10.5755/j01.ms.24.1.17545
}

Received 05 February 2017; accepted 22 May 2017

\begin{abstract}
This study evaluated the effect of thermo-treatment (THT) at 4 temperatures on the density, shrinking, mass loss, moisture absorption, color, durability in terms of resistance to decay, flexural strength, tensile adhesion of glue line and the infrared spectrum of the wood of Tectona grandis and Gmelina arborea. Sapwood, heartwood and radial and tangential grain patterns were studied. The results showed that the THT temperature decreases the density, the percentage of moisture absorption, the modulus of elasticity and modulus of rupture in the flexure test and the tensile adhesion of glue line. The percentage of shrinking and durability presented irregular behavior relative to the THT temperature. The percentage of mass loss increased with increasing THT temperature in both species. The total color change $\left(\Delta \mathrm{E}^{*}\right)$ of thermo-treated wood (THTwood) also increased with increasing THT temperature. Sapwood of T. grandis and G. arborea, having clearer shades, showed a more noticeable color change compared to hardwood; however, no significant differences were obtained between some of the THT temperatures.

Keywords: wood, thermo-treatment, dimensional stability, durability, shrinking, color, density.
\end{abstract}

\section{INTRODUCTION}

Wood is a widely used material [1]; however, it presents some inconveniences, such as dimensional changes [1] and susceptibility to damage caused by biotic and abiotic agents [2]. Due to these problems, new techniques and processes have been developed to modify and improve the properties of the wood [3]. Thermal treatment is one of those methods, used to enhance some characteristics and properties of the wood, such as dimensional stability, permeability and natural durability, among others [4].

The thermal modification or thermo-treatment (THT) is a process in which the wood is treated in an inert gas atmosphere at temperatures generally as high as $260{ }^{\circ} \mathrm{C}$ and varying times of exposure [5]. The parameters used in this process differ according to the species and conditions in which the process is executed, in order to adjust to wood dimensions, moisture content (MC) and possible use of the wood $[6,7]$. The cost of thermo-treated wood (THTwood) is lower than the cost of preservation treatments using chemical impregnation [6].

However, one of the inconveniences of THTwood is the loss of mechanical resistance. Kesik et al. [7] found changes in the mechanical properties of THTwood from four different species, i.e., reductions from 15 to $26 \%$ in hardness. Similarly, Bekhta and Niemz [8] in their research report reductions in flexural strength of approximately $50 \%$ and between 4 to $7 \%$ in the modulus of elasticity (MOE) for wood of Picea abies. Meanwhile, Gunduz et al. [9] indicated diminutions in flexural strength and compression of $7.42 \%$ and $7.55 \%$ respectively for wood of Pyrus elaeagnifolia. Likewise, Hidayat et al. [10] obtained significant reductions in the MOR and MOE for THTwood of Cylicodiscus gabunencis.

Although THT causes changes in the mechanical properties of the wood, restricting somehow the use to be given to the material, it also enhances its aesthetics and natural durability [4] as a result from color and structural changes caused by hemicellulose degradation mainly [11], which improves wood appearance and allows to implement its use in engineering, construction and architectural works, among others.

Currently, this method is not used in all countries, despite being an excellent alternative to improve the properties and characteristics of the wood. For example, in small countries such as Costa Rica, where reforestation programs using a large variety of species for timber production are implemented [12], this could become an alternative to increase the competitiveness of this type of wood in the market. This applies to reforestation species such as Tectona grandis and Gmelina arborea, which have gained commercial importance in various reforestation projects in Costa Rica [13] due to their rapid growth and their ability to adapt to abandoned areas [14]. Likewise, these woods have been well accepted in the market, which makes it worthwhile to evaluate their suitability for THT application to further enhance their properties [13].

Given this context, the objective of this research was to evaluate the effect of four THT temperatures $(205,210,215$ and $220^{\circ} \mathrm{C}$ ) for $T$. grandis wood and 4 other temperatures $\left(185,190,195\right.$ and $\left.200{ }^{\circ} \mathrm{C}\right)$ for $G$. arborea wood from trees from commercial plantations. The THT effect on the wood

\footnotetext{
* Corresponding author. Tel.: +506 550-9092; fax: +506 591-3315.

E-mail address: rmoya@itcr.ac.cr (R. Moya)
} 
of T. grandis and G. arborea were evaluated on the physical properties, like density, shrinking, weight loss, moisture absorption, color (measured by the CIEL*a*b* system), durability (by accelerated tests of resistance to natural degradation); mechanical properties, such MOR and MOE in the flexion and adhesion (by tension) test. THTwood was performed using industrial equipment seeking to obtain an environmentally friendly product, with enhanced properties and characteristics as to compete in the domestic market.

\section{EXPERIMENTAL DETAILS}

Provenance, characteristics of the material and sampling: The T. grandis and G. arborea wood was obtained from forest plantations for wood production located in the northern zone of Costa Rica, owned by the company Ethical Forestry S.A. The wood used was obtained from trees from second thinning from plantations of 11 and 8 years, with a spacing of $3 \times 3$ meters. It was selected this tree age because lumber is extracted from tree with those age. The logs were sawn into boards $7.5 \mathrm{~cm}$ wide $\times 2.5 \mathrm{~cm}$ thick $\times 250 \mathrm{~cm}$ long and radial and tangential wood samples were obtained. The wood was classified by sapwood or heartwood boards, which were then dried following the typical drying schedule at a target MC of $12 \%$ [15]. In $T$. grandis the THT was evaluated in sapwood and heartwood, including different grain patterns (radial and tangential patterns). However, it was not possible to obtain radial sapwood due to its thickness and log dimensions. In G. arborea, the thermo-treatment was studied only for radial and tangential sapwood, since it is not possible to distinguish between sapwood and hardwood. 30 boards approximately $7.5 \mathrm{~cm}$ wide $\times 2.5 \mathrm{~cm}$ thick $\times 250 \mathrm{~cm}$ long were prepared for each species. Different grain pattern was studied because the wood properties are different $[12,15]$ and they have difference performance in the THT process [6]. Finally, the boards were divided in 5 samples with $7.5 \mathrm{~cm}$ wide $\times 2.5 \mathrm{~cm}$ thick $\times 50 \mathrm{~cm}$.

Thermo-treatment process: Sawn wood in dry condition, at approximately $12 \% \mathrm{MC}$, was THT at four different temperature levels: $205,210,215$ and $220{ }^{\circ} \mathrm{C}$ for T. grandis and $185,190,195$ and $200{ }^{\circ} \mathrm{C}$ for G. arborea. The precision temperature was kept during the heat treatment of wood was \pm 2 . In addition, each species included untreated (without thermo-treatment) samples. The THT temperatures were selected considering previous results [16] where suitable temperature ranges every $5{ }^{\circ} \mathrm{C}$ were found. Samples were introduced and stacked in a Volutec $\AA$ brand oven and each THT process was performed independently. The process consisted of several drying stages during 17 hours at $130{ }^{\circ} \mathrm{C}$, until reaching $0 \% \mathrm{MC}$. Subsequently, an increase of $130{ }^{\circ} \mathrm{C}$ was applied to the temperature defined for the type of THT with a duration of 6 hours, and was held for two hours. The conditioning step was then applied for 7 hours, in which steam, water and temperature were applied to hydrate the wood and achieve about $6 \%$ MC. Finally, a cooling process was applied for 3 hours. The THT process was performed under oxygen free conditions in the presence of nitrogen.

Determination of wood density, shrinking, mass loss and moisture absorption: Each THTwood samples was measured its wood density (WD), shrinking percentage
(SP), mass loss per THT (MLT), and moisture absorption $\left(\mathrm{M}_{\mathrm{ABS}}\right)$ after the THT process. The WD was determined by the relationship between the dimension (volume) measured in samples (approx. $7.5 \mathrm{~cm}$ wide $\times 2.5 \mathrm{~cm}$ thick $\times 50 \mathrm{~cm}$ ) and the mass of each sample after the THT process. The SP was determined by measuring the width of each of the boards before and after the THT and then the difference between the two dimensions was determined and expressed in the initial measure as a percentage. For MLT, each sample was weighed before and after THT and the difference between the two masses was determined and expressed as a percentage of the initial weight. To determine MABS, 10 THTwood samples were used for each treatment conditioned to $12 \%$ with dimensions of $2 \mathrm{~cm} \times 2 \mathrm{~cm} \times$ $2 \mathrm{~cm}$. The samples were placed in a desiccator with a saturated solution of potassium nitrate at $22{ }^{\circ} \mathrm{C}(21 \%$ equilibrium moisture content). The samples were weighed weekly until they reached a constant mass. The mass before and after this period was measured and MABS was calculated with Eq. 1.

Moisture absorption $(\%)=\left(\frac{\text { Mass at } 21 \%(\mathrm{~g})-\text { Initial mass }(g)}{\text { Initial mass }(g)}\right) * 100$.

Wood color change: A HunterLab miniSkan XE Plus spectrophotometer was used for color measurement, with standardized CIE L* a* b* chromatographic system. The measuring range was 400 to $700 \mathrm{~nm}$, with an aperture at the measurement point of $11 \mathrm{~mm}$. The observation of the reflection included the specular component (SCI mode), at an angle of $10^{\circ}$, which is the normal of the surface of the specimen (D65/10); a field of view of $2^{\circ}$ (Standard observer, CIE 1931) and a level of illumination of D65 (corresponding to Daylight at 6500 Kelvin). The CIEL*a*b* color system allows three-dimensional color measurement. Color was measured in each of the boards before and after THT and the total color change $\left(\Delta \mathrm{E}^{*}\right)$ was then quantified according to ASTM D $2244[17,18]$.

Modulus of elasticity, modulus of rupture, tensile adhesion and percentage of failure of the glue line in wood: MOR and MOE were determined under the ASTM D14314 [19]. The tensile adhesion of the glue line (Ts) was performed according to the European standard UNE EN205 [20] and the percentage of failure (Fp) using the ASTM D 5266-99 standard [21]. The adhesive used was of the type Lanco ${ }^{\circledR V}$ ynil acetate Grip Bond 4 ${ }^{\mathrm{TM}}$. The tests were carried out in a universal JBA test machine, model 855 and in all cases 30 specimens were used for each species according to each treatment.

Accelerated test of resistance to natural degradation: To perform this test, 30 samples of $2 \mathrm{~cm} \times 2 \mathrm{~cm} \times 2 \mathrm{~cm}$ of the THTwood were prepared, for each species/treatment, although the wood grain patterns were not taken into account, since it was not possible define the orientation because of the dimensions of the samples used. The accelerated test for resistance to natural degradation was carried out following the methodology of the ASTM standard designation D-2017-81 [22] and the resistance to attack of the fungi $\left(\mathrm{M}_{\text {loss }}\right)$ was measured by mass loss. Two types of fungi were used: Trametes versicolor and Lenzites acuta, of white and brown decay, respectively.

Statistical analysis: The mean and standard deviation of the data were estimated for each of the properties evaluated 
in the THTwood of T. grandis and G. arborea. Subsequently, an analysis of variance (ANOVA) was performed, for which the assumptions of normality and homoscedasticity of the data were verified. The data that did not comply with the assumptions of normality or homoscedasticity were transformed through the function "standardization" provided in the statistical program InfoStat, which allowed the fulfilment of the said assumptions. The statistical program Infostat was used to perform the statistical analysis of the data. The existence of significant differences between the means of the treatments was verified by a Tukey test, using a statistical significance of $\mathrm{p}<0.05$.

\section{RESULTS AND DISCUSSION}

\subsection{Determination of density, shrinking, mass loss and moisture absorption in thermo-treated wood}

WD and SP variation for the different THT in relation to the type of wood (sapwood or hardwood) and type of grain pattern (radial or tangential) is presented in Table 1. WD diminished as the THT temperature increased, in both species, except in $T$. grandis radial hardwood THT at $210{ }^{\circ} \mathrm{C}$ and $220^{\circ} \mathrm{C}$, and tangential hardwood at $220^{\circ} \mathrm{C}$ of the same species, where increased WD was observed relative to lower THT temperatures. In addition, higher values of WD observed correspond to the control treatment.

In relation to wood SP after THT, the results showed that $T$. grandis THTwood is statistically similar between the different temperatures for the two types of wood and the two grain patterns (Table 1). However, G. arborea THTwood is statistically different at some temperatures. The range of the values obtained in SP presented a variation of between 1.20 and $2.61 \%$ in $T$. grandis and between 1.62 and $2.40 \%$ in G. arborea. Similarly, it was observed that the SP values obtained at the different temperatures for $T$. grandis did not present a specific behavior. On the contrary, the values in SP obtained for G. arborea tended to increase as the THT temperature increased, except for tangential grain patterns of THTwood at a temperature of $200{ }^{\circ} \mathrm{C}$, that showed a decrease in SP (Table 1). MLT of THTwood is shown in Fig. 1. In the case of G. arborea (Fig. 1 a), the MLT presented a similar behavior in both types of grain patterns, with a tendency to increase as the THT temperature increased. On the other hand, T. grandis THTwood (Fig. 1 b) showed similar behavior with both types of wood and grain patterns, where MLT diminished with temperatures from $205^{\circ} \mathrm{C}$ to $210^{\circ} \mathrm{C}$. Subsequently, MLT increased progressively between temperatures from $210^{\circ} \mathrm{C}$ to $220{ }^{\circ} \mathrm{C}$ (Fig. $1 \mathrm{~b}$ ).

Fig. 1 shows the variation of the MABS for the different THT in the species G. arborea and according to the type of wood (sapwood or heartwood) in T. grandis. It can be observed that the $\mathrm{M}_{\mathrm{ABS}}$ values for G. arborea (Fig. $1 \mathrm{c}$ ) presented an irregular behavior, where the THTwood at a temperature of $200{ }^{\circ} \mathrm{C}$ was the one that presented the highest MABS and the THTwood at a temperature of $185^{\circ} \mathrm{C}$ presented the lowest MABS. Similarly, for T. grandis (Fig. $1 \mathrm{~d}$ ), it was possible to observe an irregular behavior of the values between the different THT for the types of wood (sapwood and heartwood). However, it was observed that the sapwood showed higher $\mathrm{M}_{\mathrm{ABS}}$ values for all treatments compared to heartwood, with values ranging from 1.99 to $2.66 \%$ for sapwood and between 1.05 and $1.79 \%$ for hardwood (Fig. $1 \mathrm{~d}$ ). Firstly, it is important to mention that results showed that higher differences are found between grain pattern (radial or tangential) or type of wood (sapwood or heartwood than the difference between among temperature (Fig. 1, Fig. 2). This results show that the differences of used temperatures are very small and too small, therefore is invisible the influence of temperature of THT on the properties of wood.

Table 1. Wood density and shrinking percentage in wood of T. grandis and G. arborea for different types of grain pattern for sapwood and heartwood thermo-treated at four different temperatures

\begin{tabular}{|c|c|c|c|c|c|c|}
\hline \multirow{2}{*}{ Type } & \multicolumn{3}{|c|}{ Thermo-treated Tectona grandis wood } & \multicolumn{3}{|c|}{ Thermo-treated Gmelina arborea wood } \\
\hline & Temperature, ${ }^{\circ} \mathrm{C}$ & Density, $\mathrm{g} \mathrm{cm}^{-3}$ & Shrinking, $\%$ & Temperature, ${ }^{\circ} \mathrm{C}$ & Density, $\mathrm{gcm}^{-3}$ & Shrinking, $\%$ \\
\hline \multirow{5}{*}{ Radial heartwood } & Untreated & $0.56^{\mathrm{A}}$ & - & Untreated & $0.47^{\mathrm{A}}$ & - \\
\hline & 205 & $0.50^{\mathrm{B}}$ & $1.20^{\mathrm{A}}$ & 185 & $0.45^{\mathrm{AB}}$ & $1.62^{\mathrm{A}}$ \\
\hline & 210 & $0.52^{\mathrm{B}}$ & $2.09^{\mathrm{a}}$ & 190 & $0.44^{\mathrm{B}}$ & $1.86^{\mathrm{A}}$ \\
\hline & 215 & $0.49^{\mathrm{B}}$ & $2.24^{\mathrm{A}}$ & 195 & $0.44^{\mathrm{B}}$ & $2.20^{\mathrm{B}}$ \\
\hline & 220 & $0.50^{\mathrm{B}}$ & $1.90^{\mathrm{A}}$ & 200 & $0.44^{\mathrm{B}}$ & $2.33^{\mathrm{B}}$ \\
\hline \multirow{5}{*}{$\begin{array}{l}\text { Tangential } \\
\text { heartwood }\end{array}$} & Untreated & $0.60^{\mathrm{A}}$ & - & Untreated & $0.46^{\mathrm{A}}$ & - \\
\hline & 205 & $0.55^{\mathrm{B}}$ & $1.71^{\mathrm{A}}$ & 185 & $0.45 \mathrm{~A}^{\mathrm{B}}$ & $1.89^{\mathrm{A}}$ \\
\hline & 210 & $0.55^{\mathrm{B}}$ & $2.16^{\mathrm{A}}$ & 190 & $0.45 \mathrm{~A}^{\mathrm{B}}$ & $2.25^{\mathrm{AB}}$ \\
\hline & 215 & $0.54^{\mathrm{B}}$ & $1.94^{\mathrm{A}}$ & 195 & $0.45 \mathrm{~A}^{\mathrm{B}}$ & $2.40^{\mathrm{B}}$ \\
\hline & 220 & $0.55^{\mathrm{B}}$ & $2.61^{\mathrm{A}}$ & 200 & $0.43^{\mathrm{B}}$ & $2.36 \mathrm{~B}$ \\
\hline \multirow{5}{*}{$\begin{array}{c}\text { Tangential } \\
\text { sapwood }\end{array}$} & Untreated & $0.55^{\mathrm{B}}$ & $1.71^{\mathrm{A}}$ & 185 & $0.45 \mathrm{~A}^{\mathrm{B}}$ & $1.89^{\mathrm{A}}$ \\
\hline & 205 & $0.55^{\mathrm{B}}$ & $2.16^{\mathrm{A}}$ & 190 & $0.45 \mathrm{~A}^{\mathrm{B}}$ & $2.25^{\mathrm{AB}}$ \\
\hline & 210 & $0.54^{\mathrm{B}}$ & $1.94^{\mathrm{A}}$ & 195 & $0.45 \mathrm{~A}^{\mathrm{B}}$ & $2.40^{\mathrm{B}}$ \\
\hline & 215 & $0.55^{\mathrm{B}}$ & $2.61^{\mathrm{A}}$ & 200 & $0.43^{\mathrm{B}}$ & $2.36 \mathrm{~B}$ \\
\hline & 220 & $0.53^{\mathrm{C}}$ & $2.07^{\mathrm{A}}$ & - & - & - \\
\hline
\end{tabular}



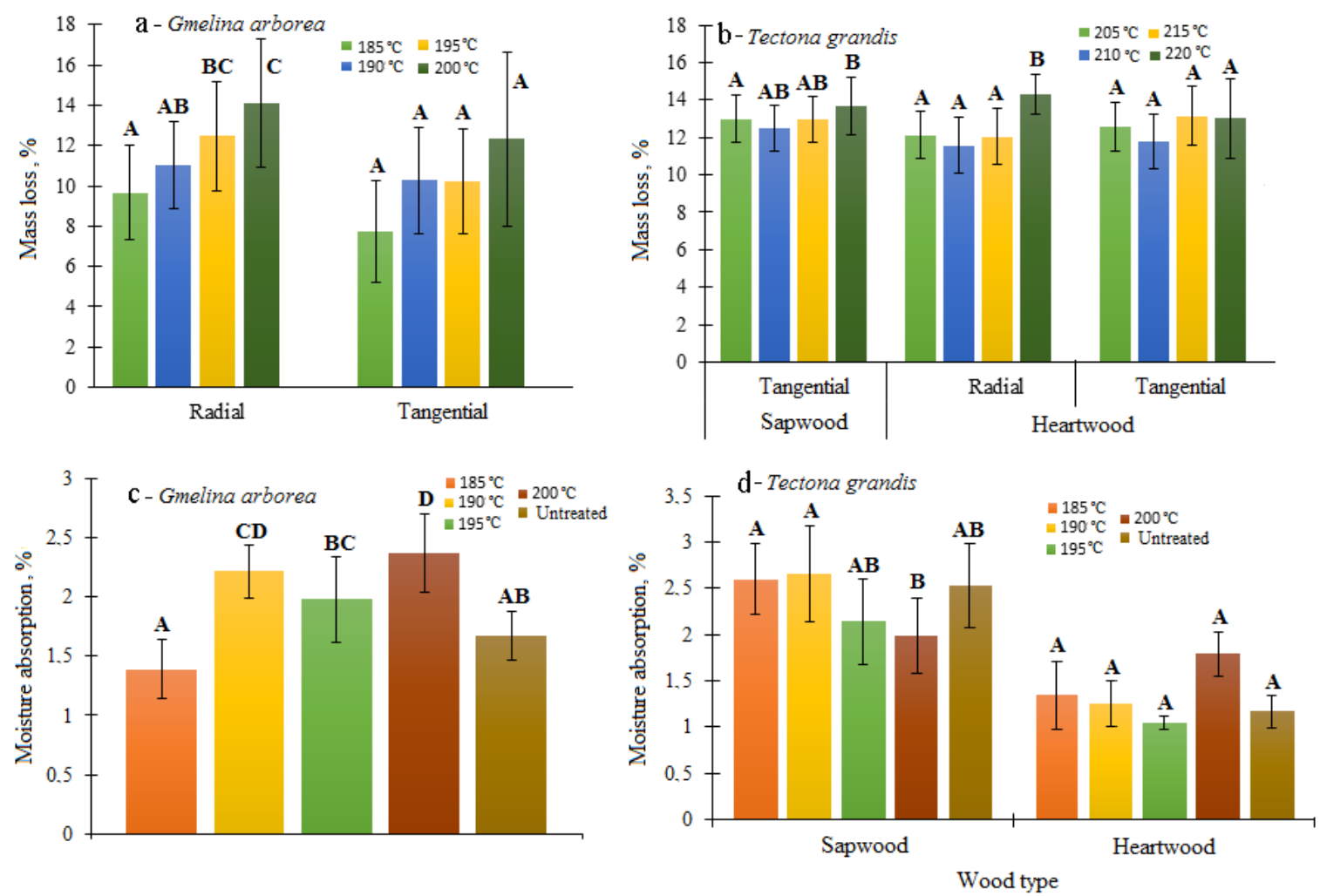

Fig. 1. a-Mass loss in wood of G. arborea; b-mass loss in wood of T. grandis after thermo-treatment and moisture absorption in wood of $\mathrm{c}-G$. arborea and d-T. grandis thermowood for different types of grain pattern for sapwood and heartwood heat treated at four different temperatures. Legend: the error shows standard deviation and values identified with different letters are statistically different at $\alpha=95 \%$

The decrease in WD of THTwood treated at different temperatures in the two wood types and grain patterns of T. grandis and G. arborea (Table 1) is congruent with reports of THTwood of Pinus sylvestris [23], Pyrus elaeagnifolia [9] and T. grandis [16]. This decrease in WD is associated to $\mathrm{ML}_{\mathrm{T}}$ of the wood during the THT [24], as confirmed by the results obtained in the THTwood of G. arborea and T. grandis (Fig. 2 a, b). It was observed that $\mathrm{ML}_{\mathrm{T}}$ in the wood increased with increasing THT temperature (Fig. 2 a, b), which is congruent with reports on Tilia cordata Mill [4] and on THTwood of Fagus orientalis [25]. The $M L_{T}$ is attributed to the degradation of wood components (mainly hemicelluloses), produced by chemical reactions during the THT process, which causes the volatilization of wood extractives [26]. This thermal degradation causes a loss of weight in the wood, which is one of the most important indicators of the quality or the degree of the THT applied [27].

Not in all cases an increase in $\mathrm{ML}_{\mathrm{T}}$ with THT temperature occurs [1]. For example, there were no statistically significant differences by temperature in this study with regard to the THT tangential-grain wood of G. arborea (Fig. 1 a) and in THT tangential-grain heartwood of T. grandis (Fig. $1 \mathrm{~b}$ ). In these cases, THT temperatures do not lead to significant changes in the loss of wood components and extractives. However, when $\mathrm{ML}_{\mathrm{T}}$ increases with temperature, for example, in G. arborea THT radial wood (Fig. 1 a) and in tangential and radial grain patterns of sapwood and hardwood of $T$. grandis (Fig. $1 \mathrm{~b}$ ), it is due to high temperatures and prolonged times that produce a reduction of the mass [9].
WD reduction is one of the main indicators of the degree of THT [27], higher values of $\mathrm{ML}_{\mathrm{T}}$ being obtained at higher temperatures. However, no significant differences were found between the THT temperatures of both species, except for tangential-grain sapwood at $205^{\circ} \mathrm{C}$, where significant differences with respect to the rest of THT temperatures were obtained (Table 1). This slight difference between WD of THTwood at the different temperatures can be explained by Gunduz et al. [9] and Uribe and Ayala [1], who point out that, although there is a decrease of the wood weight and volume with THT, such diminution is not significant as to cause a perceptible change in WD. Besides, our study, probably it was necessary to increase wood samples to increase results accuracy, especially statistical differences.

Regarding the SP of THTwood of both species, these values have the advantage of being lower than those of the International Thermowood Association [23], which indicates shrinking parameters for this type of wood between 5 and $8 \%$, while in this study the values range between 1.20 to $2.61 \%$ (Table 1 ).

In general, with few exceptions, an increase in $\mathrm{ML}_{\mathrm{T}}$ with increasing THT temperature was observed in both species (Table 1). This is because during THT process the wood is subjected to high temperatures that eliminate the water in the wood cell wall [28], therefore the shrinking. On the other hand, high SP values are expected in wood treated at high temperatures and in tangential grain pattern, for the reason that in this direction the strengths of the radiuses do not interfere due to the orientation of the parenchyma cells $[29,30]$. This behavior was observed in T. grandis thermo- 
treated wood, where the highest shrinking percentages were obtained in tangential hardwood at a temperature of $220^{\circ} \mathrm{C}$, whereas in G. arborea wood the greatest shrinking was obtained in tangential thermo-treated wood at a temperature of $200{ }^{\circ} \mathrm{C}$ (Table 1). However, some inconsistencies were found in the THTwood, for example, T. grandis heartwood, THT at $215^{\circ} \mathrm{C}$, showed greater shrinking in the radial direction with respect to shrinking in the tangential direction of sapwood and hardwood (Table 1). This behavior can be attributed to other factors such as the presence of juvenile wood [31], which presents high shrinking in the radial direction, or that the samples were obtained from central parts of the log, which is characterized by high presence of juvenile wood.

In THTwood, $\mathrm{M}_{\mathrm{ABS}}$ tends to decrease with increasing THT temperature, due to its greater permeability caused by the chemical changes during the process [9], such as the removal of volatiles and organic compounds [1], mainly hydrophilic agents in wood [32]. Gunduz et al. [9] indicate that the THT significantly reduces radial and tangential stresses, resulting in lower $\mathrm{M}_{\mathrm{ABS}}$, changes that begin to occur at approximately $150{ }^{\circ} \mathrm{C}$ and intensify as the temperature increases. However, such behavior was not observed in the present study. The $\mathrm{M}_{\mathrm{ABS}}$ in the THTwood increased in the different THT temperatures for the grain pattern types in G. arborea (Fig. $1 \mathrm{c}$ ). In the case of T. grandis THTwood (Fig. $1 \mathrm{~d}$ ), no THT temperature produced a decrease of $\mathrm{M}_{\mathrm{ABS}}$ in either sapwood or heartwood in relation to wood without THT.

Lack of improvement of $\mathrm{M}_{\mathrm{ABS}}$ through THT in both species studied can be attributed to low $\mathrm{M}_{\mathrm{ABS}}$ of the wood and good dimensional stability $[12,31]$. Thus, thermotreatment can cause few effects on water-related components and therefore few effects on $\mathrm{M}_{\mathrm{ABS}}$ in THTwood, as found in the present study.

Fig. 2 shows the results obtained in the measurement of the total color change $\left(\Delta \mathrm{E}^{*}\right)$. In $G$. arborea THTwood (Fig. 2 a), the behavior of the $\Delta \mathrm{E}^{*}$ values is similar in both types of grain patterns, with a decrease of $\Delta \mathrm{E}^{*}$ in the THTwood from $185^{\circ} \mathrm{C}$ to $190{ }^{\circ} \mathrm{C}$. Subsequently, there was an increase of $\Delta \mathrm{E}^{*}$ as the THT temperature increased. Meanwhile, for $T$. grandis (Fig. 2 b), a similar behavior was again observed between different types of wood and grain patterns. THTwood at a temperature of $205{ }^{\circ} \mathrm{C}$ showed the highest $\Delta \mathrm{E}^{*}$ values. Furthermore, a decrease in $\Delta \mathrm{E}^{*}$ was obtained from $205^{\circ} \mathrm{C}$ to $210^{\circ} \mathrm{C}$, and an increase later in $\Delta \mathrm{E}^{*}$ with the increase of the THT temperature (from 210 to $220^{\circ} \mathrm{C}$ ), (Fig. 2 b).

The change in perceptible color in the THTwood is related to the changes that the human eye perceives and this can be evaluated with the $\Delta \mathrm{E}^{*}$ [15]. It was found that, regardless of the species or grain pattern in the wood, there was a tendency to increase the $\Delta \mathrm{E}^{*}$ (high color change perceptible to the human eye) with the increase of the thermo-treatment temperature, coinciding with what was reported by the International Thermowood Association [23] for THTwood of Pinus sylvestris. Also, higher values of $\Delta \mathrm{E}^{*}$ were obtained in sapwood for T. grandis and $G$. arborea for being woods with whiter shades that when subjected to a THT process show a more noticeable color change compared to heartwood, where $\Delta \mathrm{E}^{*}$ is slightly less appreciable. However, in this type of white wood, the temperature range used has little $\Delta \mathrm{E}^{*}$ effect, since there were no statistically significant differences between some of the THT temperatures (Fig. 2). Again, our study, probably it was necessary to increase wood samples to increase results accuracy, especially statistical differences.

The color changes obtained after applying THT to the wood are mainly caused by the hydrolysis of the hemicelluloses [9,33]. Hemicelluloses appear in the presence of essential components of wood, such as extractives, which not only contribute to color change [27] but also cause a decrease in the white tone ( $\mathrm{L}^{*}$ decrease). These changes are attributed to the degradation or modification of components through reactions such as oxidation, dehydration, decarboxylation and hydrolysis [26], as well as the darkening of lignin, linked to the generation of chromophore groups [11], which cause more noticeable color changes in woods such as $G$. arborea and in sapwood in T. grandis, since their shade is clearer.

In turn, Bourgois et al. [34] mention that diminution of the content of hemicelluloses, pentose in particular, in thermo-treated wood at $240-310^{\circ} \mathrm{C}$, causes an increase in $\Delta \mathrm{E}^{*}$. This change is also associated with some functional groups as carbonyl, lignin structures, hemicelluloses or quinoid structures, linked to the generation of substances that produce color in THTwood [35].
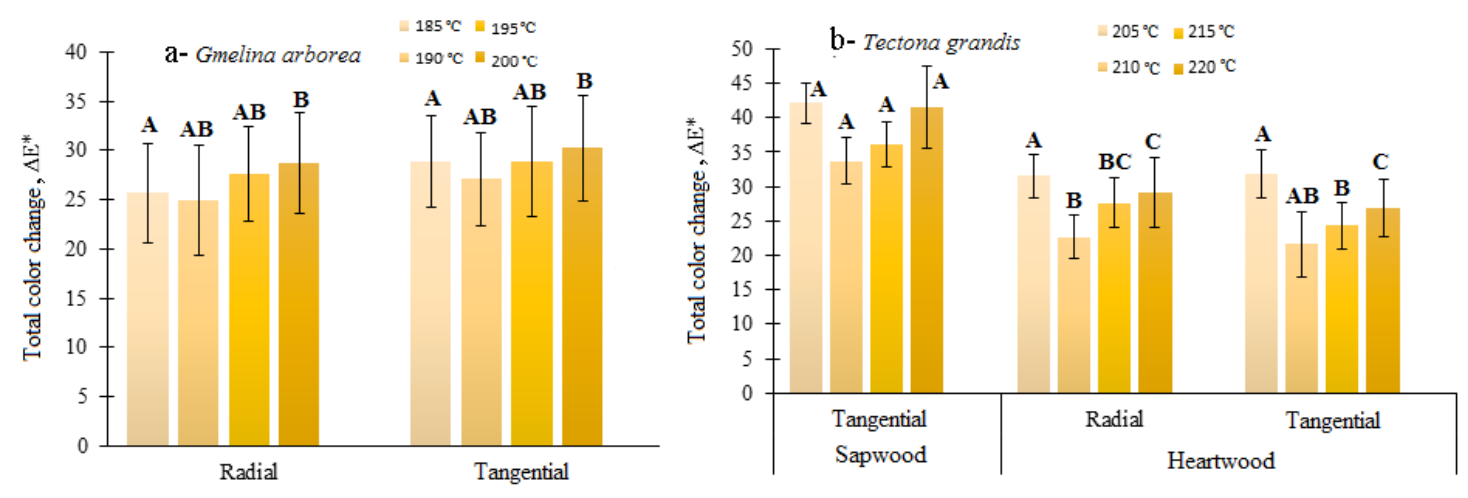

Fig. 2. a - total color change $\left(\Delta \mathrm{E}^{*}\right)$ in wood of G. arborea; b-T. grandis for different types of grain pattern for sapwood and heartwood thermo-treated at four different temperatures. Legend: the error shows standard deviation and values identified with different letters are statistically different at $\alpha=95 \%$ 


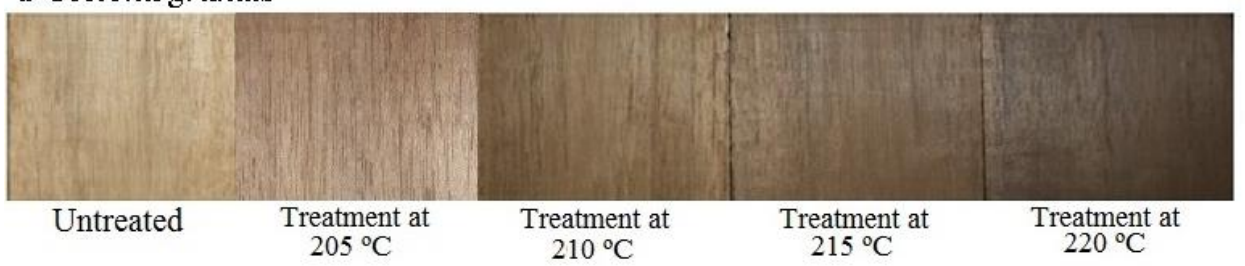

b- Gmelina arborea

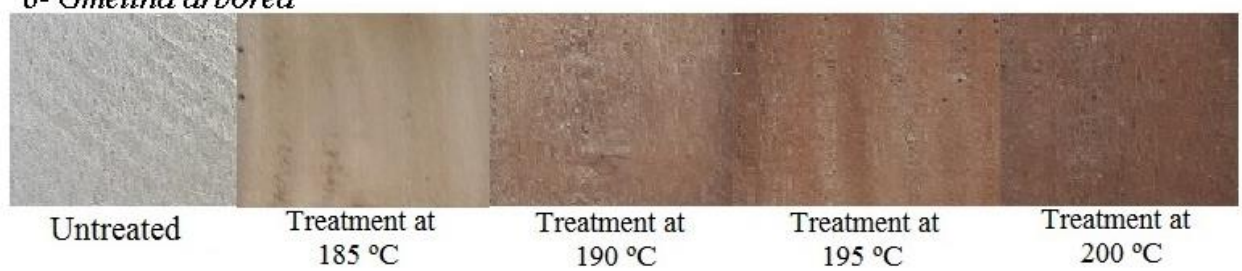

Fig. 3. $\mathrm{a}$-color changes in the wood of Tectona grandis; $\mathrm{b}$-Gmelina arborea, according to the different thermo-treatment temperatures defined

Chen et al. [33] indicate that modification of wood components as hemicellulose and lignin degradation, as well as the presence of residual extractives due to wood exposure to high temperatures causes wood color to change. This change is more noticeable as the THT temperature increases. Thermal degradation is directly related to the degree of darkening of the properties of the color and the total color change $\left(\Delta \mathrm{E}^{*}\right)$, which depend on the conditions of the thermal treatment applied [11] and, as a result, the color changes are visually appreciable (Fig. 3).

\subsection{Determination of the modulus of elasticity and modulus of rupture in flexion test in thermo- treated wood}

Fig. 4 shows the mechanical properties evaluated in THTwood. The MOE for G. arborea presented similar
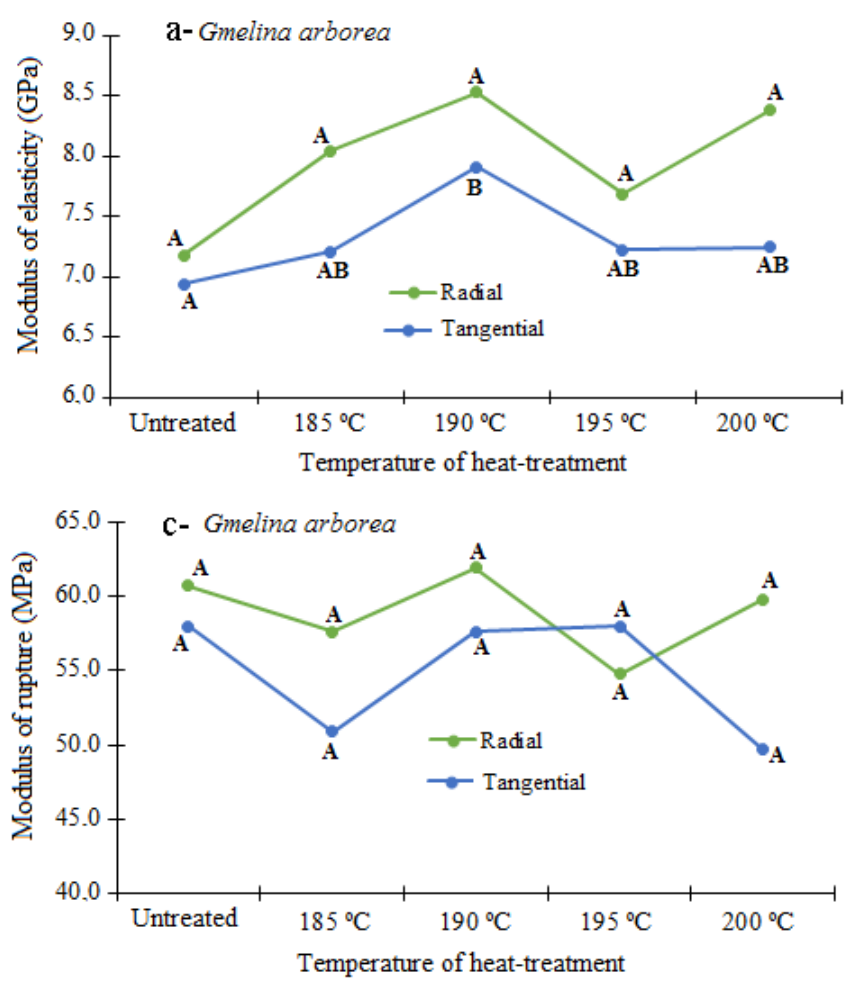

irregular trend between the two types of grain patterns (Fig. 4 a). This property increased continuously from the control treatment to THTwood at $190{ }^{\circ} \mathrm{C}$, diminished later in THTwood at $190{ }^{\circ} \mathrm{C}$ and $195^{\circ} \mathrm{C}$, increased again at $195{ }^{\circ} \mathrm{C}$ and $200{ }^{\circ} \mathrm{C}$ (Fig. 4 a). The values of MOE in T. grandis (Fig. 4 b) presented an irregular behavior between the different temperatures, with tangential sapwood and radial heartwood presenting the higher values of MOE, except for the thermo-treated wood at $205^{\circ} \mathrm{C}$. In turn, the treatment at $210{ }^{\circ} \mathrm{C}$ presented the highest values in MOE for tangential sapwood and radial heartwood. As for tangential heartwood, the highest MOE values were obtained in the treatment at $205^{\circ} \mathrm{C}$ (Fig. 4 b).
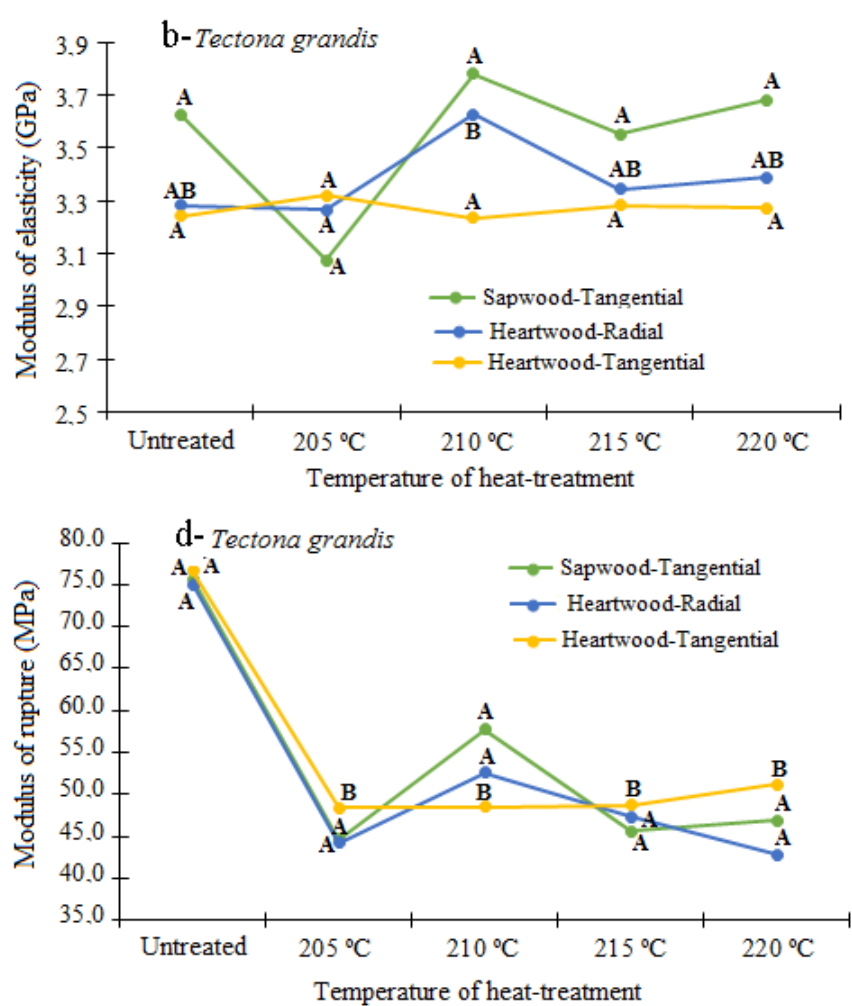

Fig. 4. MOE and MOR in wood for different types of grain pattern for sapwood and heartwood heat treated at four different temperatures: a-MOE in G. arborea; b-MOE in T. grandis; c-MOR in G. arborea and d-MOR in T. grandis. Legend: the error shows standard deviation and values identified with different letters are statistically different at $\alpha=95$ 
The results obtained in the MOR in flexion test show that the variation of the data in G. arborea (Fig. 4 c) was irregular between the different THT temperatures for both types of grain patterns (radial and tangential). The MOR presented an increase-decrease behavior as the established THT temperatures changed, i.e., a decrease in the values of the THTwood at $185^{\circ} \mathrm{C}$ in relation to the wood without THT. But there is an increase in the values of the THTwood at $190{ }^{\circ} \mathrm{C}$ in relation to the THTwood at $185^{\circ} \mathrm{C}$, followed by a decrease and increase of the MOR values in THTwood at $195{ }^{\circ} \mathrm{C}$ and $200{ }^{\circ} \mathrm{C}$ respectively (Fig. 4 c), except for the treatment at $195{ }^{\circ} \mathrm{C}$ for the tangential grain pattern, which presented values similar to the THT at $190{ }^{\circ} \mathrm{C}$, without showing much variation. For T. grandis (Fig. 4 d), it was found that the MOR presented a similar behavior between the different types of wood and types of grain patterns, being the values of tangential heartwood those that presented the smaller variation between the different treatments applied. In the same way, a decrease of the MOR was observed between the values of the wood without THT in relation to the values obtained from the samples to which the THT was applied (Fig. 4 d).Although variation among the values of MOR obtained for THTwood of both G. arborea (Fig. 4 c) and of T. grandis (Fig. $4 \mathrm{~d}$ ) in the different THT temperatures could be noticed, no significant differences could be established between the temperatures for the various types of wood and grain patterns analyzed (Fig. 4). The differences of used temperatures are very small and too small, therefore is invisible the influence of temperature of THT on the properties of wood. However, values of MOR and MOE for T. grandis (Fig. 4 d) decreased with the THT, coinciding with the International Thermowood Association [23], who indicates for Pinus sylvestris that MOR and MOE reductions and higher resistance losses were evident at temperatures above $220{ }^{\circ} \mathrm{C}$, therefore THTwood for structural uses is not recommended. The weakening of the mechanical properties arises from the modification of the wood due to the chemical degradation of polymers [27]. According to Awoyemi and Jones [36], the reduction in MOR and MOE values is due to the degradation of tracheid walls - which in turn coincides with the degradation of the hemicelluloses, one of the main components of the cell wall - and because of the increasing content of crystalline cellulose and replacement of flexible hemicellulosecellulose-hemicellulose bonds with more rigid cellulosecellulose bonds [26].

Another important aspect indicated by Bal [37] regarding THTwood, is the decrease in the mechanical strength of the wood, which is higher as the THT temperature increases, due to hemicelluloses and celluloses becoming more rigid [26, 39]. The THT not always reduces the mechanical properties of the wood. Kocaefe et al. [39] found that both MOR and MOE increased up to a THT temperature of $160{ }^{\circ} \mathrm{C}$, and then both decreased as the temperature increased.

\subsection{Determination of the tensile adhesion and percentage of glue line failure in thermo- treated wood}

The values of Ts presented a tendency to decrease with increasing thermo-treatment temperature, except for the tangential sapwood at $215^{\circ} \mathrm{C}$, which presented an increase of Ts in relation to the THTwood at $210^{\circ} \mathrm{C}$ (Table 2). Also, wood without THT presented the highest Ts values for each of the wood types and grain patterns in both species. Regarding the parameter Fp, wood and grain patterns of the species did not present any specific behavior, except for tangential heartwood of T. grandis, which presented a tendency to diminish the Fp with increasing THT temperature (Table 2). The Ts by traction of overlapping joints is shown in Table 2, which shows that the resistance decreases as the THT temperature increases in both species, regardless of the type of wood and type of grain pattern defined.

Table 2. Tensile adhesion and failure percentage of the glue line in wood of G. arborea and T. grandis for different types of grain pattern for sapwood and heartwood heat treated at four different temperatures

\begin{tabular}{|c|c|c|c|c|c|c|}
\hline \multirow[b]{2}{*}{ Type } & \multicolumn{3}{|c|}{ Thermo-treated Tectona grandis wood } & \multicolumn{3}{|c|}{ Thermo-treated Gmelina arborea wood } \\
\hline & $\begin{array}{c}\text { Temperature, } \\
{ }^{\circ} \mathrm{C}\end{array}$ & $\begin{array}{c}\text { Tensile adhesion, } \\
\mathrm{MPa}\end{array}$ & $\begin{array}{c}\text { Failure of glue line, } \\
\%\end{array}$ & \begin{tabular}{|c|} 
Temperature, \\
${ }^{\circ} \mathrm{C}$
\end{tabular} & $\begin{array}{c}\text { Tensile adhesion, } \\
\mathrm{MPa}\end{array}$ & $\begin{array}{c}\text { Failure of glue line, } \\
\%\end{array}$ \\
\hline \multirow{5}{*}{ Radial heartwood } & Untreated & $9.40^{\mathrm{A}}$ & $81.89^{\mathrm{A}}$ & Untreated & $8.01^{\mathrm{A}}$ & $84.39^{\mathrm{A}}$ \\
\hline & 205 & $3.10^{\mathrm{A}}$ & $77.78^{\mathrm{A}}$ & 185 & $4.50^{\mathrm{A}}$ & $53.17^{\mathrm{A}}$ \\
\hline & 210 & $2.85^{\mathrm{A}}$ & $61.78^{\mathrm{A}}$ & 190 & $4.95^{\mathrm{A}}$ & $70.17^{\mathrm{A}}$ \\
\hline & 215 & $2.46^{\mathrm{A}}$ & $43.78^{\mathrm{A}}$ & 195 & $4.28^{\mathrm{A}}$ & $75.33^{\mathrm{A}}$ \\
\hline & 220 & $2.58^{\mathrm{A}}$ & $63.72^{\mathrm{A}}$ & 200 & $4.13^{\mathrm{A}}$ & $80.81^{\mathrm{A}}$ \\
\hline \multirow{5}{*}{$\begin{array}{l}\text { Tangential } \\
\text { heartwood }\end{array}$} & Untreated & $11.52^{\mathrm{A}}$ & $55.06^{\mathrm{A}}$ & Untreated & $8.69^{\mathrm{A}}$ & $57.33^{\mathrm{A}}$ \\
\hline & 205 & $5.54^{\mathrm{A}}$ & $51.50^{\mathrm{A}}$ & 185 & $6.35^{\mathrm{A}}$ & $64.56^{\mathrm{AB}}$ \\
\hline & 210 & $4.54^{\mathrm{A}}$ & $48.06^{\mathrm{A}}$ & 190 & $5.34^{\mathrm{A}}$ & $81.89^{\mathrm{B}}$ \\
\hline & 215 & $4.07^{\mathrm{A}}$ & $46.33^{\mathrm{A}}$ & 195 & $5.75^{\mathrm{A}}$ & $60.83^{\mathrm{AB}}$ \\
\hline & 220 & $3.34^{\mathrm{A}}$ & $18.83^{\mathrm{A}}$ & 200 & $5.28^{\mathrm{A}}$ & $78.94^{\mathrm{AB}}$ \\
\hline \multirow{5}{*}{ Tangential sapwood } & Untreated & $11.52^{\mathrm{A}}$ & $69.33^{\mathrm{A}}$ & - & - & - \\
\hline & 205 & $4.84^{\mathrm{A}}$ & $72.61^{\mathrm{A}}$ & - & - & - \\
\hline & 210 & $4.24^{\mathrm{A}}$ & $60.94^{\mathrm{AB}}$ & - & - & - \\
\hline & 215 & $5.45^{\mathrm{A}}$ & $41.33^{\mathrm{BC}}$ & - & - & - \\
\hline & 220 & $3.13^{\mathrm{A}}$ & $26.39^{\mathrm{C}}$ & - & - & - \\
\hline
\end{tabular}


However, despite this decrease, no statistically significant differences were found between the different THT temperatures. Regarding the wood Fp, T. grandis presented a decrease with increasing THT temperature, indicating that THTwood at higher temperatures showed higher Fp. However, significant differences were only observed in the sapwood with tangential grain. On the other hand, the wood of $G$. arborea showed irregular behavior in relation to the $\mathrm{Fp}$, as only the wood with tangential grain presented statistically significant differences.

In addition, it can be observed that the G. arborea THTwood had values of Ts slightly higher than those of T. grandis, which may be due to the fact that the THTwood of $T$. grandis used higher THT temperatures, resulting in greater wood fragility [25]. On the other hand, Kuzman et al. [40] indicate an increase in the tensile adhesion in bonded wood joints of Fagus sylvatica and Picea abies when heat treated at $190{ }^{\circ} \mathrm{C}$, compared to non-thermo-treated samples. However, these authors did not obtain significant differences in the strength of the joints glued in THTwood at different temperatures, coinciding with results from this study where no statistically significant differences were found (Table 2). Ts decrease occurs mainly due to the degradation of hemicelluloses, which are less heat stable than cellulose and lignin $[35,40]$. In addition, the increase in Fp values is due to the breakdown of $\mathrm{OH}$ bonds and volatilization of extractives due to heat, which interferes with the quality of the bond between the adhesive and the substrate [26].

\subsection{Determination of durability in accelerated tests of resistance to natural degradation of thermo- treated wood}

The $\mathrm{M}_{\text {loss }}$ values were particularly irregular for the two types of fungi (L. acuta and T. versicolor) used in the test and the different THT temperatures (Table 3). T. grandis untreated wood (control treatment) showed statistically higher values of $\mathrm{M}_{\text {loss }}$ for both types of wood (sapwood and heartwood) with both types of fungi. Meanwhile, the lower values of $\mathrm{M}_{\text {loss }}$ in $T$. grandis sapwood were obtained in the THTwood at $205^{\circ} \mathrm{C}$ with L. acuta, and at $220{ }^{\circ} \mathrm{C}$ with $\mathrm{T}$. versicolor, whereas in heartwood, the lowest $\mathrm{M}_{\text {loss }}$ was obtained in the THTwood at $210{ }^{\circ} \mathrm{C}$ for both types of fungi (Table 3). For G. arborea the highest values of $\mathrm{M}_{\text {loss }}$ were observed in the THTwood at $200{ }^{\circ} \mathrm{C}$ and $190{ }^{\circ} \mathrm{C}$ for L. acuta and T. versicolor, respectively, and the lower values corresponded to THTwood at $190{ }^{\circ} \mathrm{C}$ and $195^{\circ} \mathrm{C}$ for L. acuta and T. versicolor, respectively (Table 3). The $\mathrm{M}_{\text {loss }}$ accelerated test of resistance to fungal decay (Table 3) classified the THTwood in the different temperatures and different types of fungi between "highly resistant" and "resistant" to the fungi T. versicolor and L. acuta. This according to the ASTM 2017 standard [22], since the M loss values are between 0 and $24 \%$, contrasting with untreated sapwood of $T$. grandis species, which presents $\mathrm{M}_{\text {loss }}$ values above $25 \%$ for $T$. versicolor, cataloging it as "moderately resistant" based on the aforementioned norm. An important aspect to be mentioned is that the THTwood at different temperatures showed no statistically significant differences between the different THT temperatures and the wood without THT (Table 3). This coincides with Kamdem et al. [41], who mention that $\mathrm{M}_{\text {loss }}$ obtained for THTwood of Fagus sylvatica, Pinus sp. and Picea abies exposed to two brown rot fungi (Gloeophyllum trabeum and Poria placentra) and a white rot (Irpex lacteus), did not present significant differences between the THT temperatures used (between 200 and $206^{\circ} \mathrm{C}$ ).

According to Venäläinen et al. [42], $\mathrm{M}_{\mathrm{loss}}$ caused by fungi is due initially to polysacarid degradation (cellulose and hemicellulose) and later, at more advanced stages of brown rot fungus, to lignin degradation, while white rot fungi degrade lignin first and then hemicellulose, aspects that are reflected when applying the THT. According to Calonego et al. [43], the increase in resistance to disintegration caused by fungal attack is related to duration and THT temperature, being more evident at higher exposure times and temperatures. This is because the higher the THT temperatures, the higher the decrease in moisture, hemicelluloses, as well as lipids, starch and some fatty acids necessary for fungal growth and capacity of action [39].When comparing the results obtained in this study with the two wood species (Table 3), it can be observed that G. arborea presented $\mathrm{M}_{\text {loss }}$ per attack higher than those obtained in $T$. grandis with both types of fungus.

Table 3. Weight loss by Lenzites acuta and Trametes versicolor in wood of G. arborea and T. grandis for different types of grain pattern for sapwood and heartwood heat treated at four different temperatures

\begin{tabular}{|c|c|c|c|c|c|c|}
\hline \multirow{3}{*}{ Type } & \multicolumn{3}{|c|}{ Thermo-treated Tectona grandis wood } & \multicolumn{3}{c|}{ Thermo-treated Gmelina arborea wood } \\
\cline { 2 - 7 } & $\begin{array}{c}\text { Temperature, } \\
{ }^{\circ} \mathrm{C}\end{array}$ & $\begin{array}{c}\text { Lenzites acuta, } \\
\%\end{array}$ & $\begin{array}{c}\text { Trametes versicolor, } \\
\%\end{array}$ & $\begin{array}{c}\text { Temperature, } \\
{ }^{\circ} \mathrm{C}\end{array}$ & $\begin{array}{c}\text { Lenzites acuta, } \\
\%\end{array}$ & $\begin{array}{c}\text { Trametes ersicolor, } \\
\%\end{array}$ \\
\hline \multirow{5}{*}{ Sapwood } & Untreated & $14.76^{\mathrm{A}}$ & $29.32^{\mathrm{A}}$ & Untreated $^{\mathrm{A}}$ & $19.44^{\mathrm{A}}$ & $17.76^{\mathrm{A}}$ \\
\cline { 2 - 7 } & 205 & $8.31^{\mathrm{A}}$ & $12.14^{\mathrm{A}}$ & 185 & $19.48^{\mathrm{A}}$ & $11.95^{\mathrm{A}}$ \\
\cline { 2 - 7 } & 210 & $13.20^{\mathrm{A}}$ & $12.20^{\mathrm{A}}$ & 190 & $24.09^{\mathrm{A}}$ & $6.65^{\mathrm{A}}$ \\
\cline { 2 - 7 } & 215 & $9.46^{\mathrm{A}}$ & $6.82^{\mathrm{A}}$ & 195 & $19.05^{\mathrm{A}}$ & $22.44^{\mathrm{A}}$ \\
\cline { 2 - 7 } & 220 & $13.55^{\mathrm{A}}$ & $4.90^{\mathrm{A}}$ & 200 & $17.19^{\mathrm{A}}$ & - \\
\hline \multirow{5}{*}{ Heartwood } & Untreated & $13.91^{\mathrm{A}}$ & $6.33^{\mathrm{A}}$ & - & - & - \\
\cline { 2 - 7 } & 205 & $10.83^{\mathrm{A}}$ & $4.72^{\mathrm{A}}$ & - & - & - \\
\cline { 2 - 7 } & 210 & $9.65^{\mathrm{A}}$ & $1.97^{\mathrm{A}}$ & - & - & - \\
\cline { 2 - 7 } & 215 & $12.60^{\mathrm{A}}$ & $3.07^{\mathrm{A}}$ & - & - & - \\
\cline { 2 - 7 } & 220 & $11.85^{\mathrm{A}}$ & $4.53^{\mathrm{A}}$ & - & & - \\
\hline
\end{tabular}


Paul et al. [44] reported a slight increase in resistance to fungal degradation when the wood is THT at temperatures below $200{ }^{\circ} \mathrm{C}$, as applied to the wood of G. arborea, which can explain the difference. In fact, authors such as Jämsä et al. [45] (1999) recommend using a minimum temperature of THT of $220{ }^{\circ} \mathrm{C}$ to achieve a significant increase in the resistance to the decomposition by fungi, aspects that were not applied in this study and could be influencing the results obtained.

\section{CONCLUSIONS}

According to the findings of this study, it was possible to determine that the thermal treatment, in both $T$. grandis and G. arborea, influences the properties of the wood, favoring some and affecting others. The differences of used temperatures are very small and too small, therefore is invisible the influence of temperature of THT on the properties of wood, but the higher change was observed in wood color. In order to achieve the best characteristics of the material, a balance between the desired and the optimal characteristic must be made. This depends on the purpose for which the wood is being heat treated. If the aim is obtain wood with an enhanced color and greater durability for uses where little effort is required, then high thermo-treatment temperatures are recommended. On the contrary, if what is needed is material with better mechanical properties, then lower thermo-treatment temperatures are advisable, taking into account that wood with less color changes and less durability will be produced, among other aspects.

\section{Acknowledgments}

We thank the Vicerrectoría de Investigación y Extensión from Instituto Tecnológico de Costa Rica (ITCR) for funding this study. We also thank Ethical Forestry S.A. for providing the samples and some equipment needed to develop this study.

\section{REFERENCES}

1. Uribe, B.E., Ayala, O.A. Characterization of Three Wood Species (Oak. Teak and Chanul) Before and After Heat Treatment Journal of the Indian Academy of Wood Science 12 (1) 2015: pp. 54-62.

https://doi.org/10.1007/s13196-015-0144-4

2. Ortiz, R., Párraga, M., Navarrete, J., Carrasco, I., de la Vega, E., Ortiz, M., Blanchette, R.A. Investigations of Biodeterioration by Fungi in Historic Wooden Churches of Chiloé, Chile Microbigia Ecológica 67 (10) 2014: pp. $568-575$.

https://doi.org/10.1007/s00248-013-0358-1

3. Kocaefe, D., Huang, X., Kocaefe, Y. Dimensional Stabilization of Wood Current Forestry Reports 1(2) 2015: pp. $151-161$. https://doi.org/10.1007/s40725-015-0017-5

4. Olarescu, M.C., Campean, M., Ispas, M., Cosereanu, C. Effect of Thermal Treatment on Some Properties of Lime Wood European Journal of Wood and Wood Products 72 (10) 2014: pp. 559-562. https://doi.org/10.1007/s00107-014-0809-5

5. Ansell, M.P. Wood: A 45th anniversary review of JMS papers. Part 1: The Wood Cell Wall and
Mechanical Properties Journal of Materials Science 46 (23) 2011: pp. $7357-7368$.

https://doi.org/10.1007/s10853-011-5856-2

6. Esteves, B., Nunes, L., Domingos, I., $\quad$ Pereira, $\mathbf{H}$. Comparison Between Heat Treated Sapwood and Heartwood from Pinus pinaster European Journal of Wood and Wood Products 72 2014: pp. 53-60. https://doi.org/10.1007/s00107-013-0751-y

7. Kesik, H.I., Korkut, S., Hiziroglu, S., Sevik, H. An Evaluation of Properties of Four Heat Treated Wood Species Indutrial Crops and Products 60 (1) 2014: pp. 60-67. https://doi.org/10.1016/j.indcrop.2014.06.001

8. Bekhta, P., Niemz, P. Effect of High Temperature on the Change in Color Dimensional Stability and Mechanical Properties of Spruce Wood Holzforschung 57 (5) 2003: pp. 539-546. https://doi.org/10.1515/HF.2003.080

9. Gunduz, G., Aydemir, D., Karakas, G. The Effects of Thermal Treatment on The Mechanical Properties of Wild Pear (Pyrus elaeagnifolia Pall.) Wood and Changes in Physical Properties Materials and Design 30 2009: pp. $4391-4395$.

https://doi.org/10.1016/j.matdes.2009.04.005

10. Hidayat, W., Qi, Y., Jang, J.H., Febrianto, F., Lee, S.H., Kim, N.H. Effect of Treatment Duration and Clamping on The Properties of Heat-Treated Okan Wood BioResources 11 2016: pp. 10070-10086. https://doi.org/10.15376/biores.11.4.10070-10086

11. Salca, E.A., $\quad$ Kobori, H., Inagaki, T., Kojima, Y., Suzuki, S. Effect of Heat Treatment on Colour Changes of Black Alder and Beech Veneers Journal of Wood Science 62 2016: pp. 297-307. https://doi.org/10.1007/s10086-016-1558-3

12. Moya, R. Wood of Gmelina arborea in Costa Rica New Forest 28 2004: pp. 299-307.

13. Serrano, R., Moya, R. Procesamiento, Uso y Mercado de la Madera en Costa Rica: Aspectos Históricos y Análisis Crítico Revista Forestal Mesoamericana 9 (21) 2011: pp. 1-12.

14. Moya, R., Tenorio, C. Fuelwood Characteristics and Its Relation with Extractives and Chemical Properties of Ten Fast-Growth Species in Costa Rica Biomass and Bioenergy 56 2013: pp. 14-21. https://doi.org/10.1016/j.biombioe.2013.04.013

15. Salas, C., Moya, R. Kiln-, Solar-, and Air-Drying Behavior of Lumber of Tectona Grandis and Gmelina Arborea from Fast-Grown Plantations: Moisture Content, Wood Color, and Drying Defects Drying Technology 32 2014: pp.301-310. http://dx.doi.org/10.1080/07373937.2013.829087

16. Méndez-Mejías, L.D., Moya, R. Effects on Density, Shrinking, Color Changing and Chemical Surface Analysis Through FTIR of Tectona Grandis Thermo-Treated Scientia Forestalis 44 (112) 2016: pp. 802-811.

17. Berrocal, A., Moya, R., Rodriguez-Solis, M., Starbird, R., Muñoz, F. Surface Chemical and Color Characterization of Juvenile Tectona Grandis Wood Subjected to Steam-Drying Treatments Surface Review and Letters 23 (01) 2016: pp. $1-14$. https://doi.org/10.1142/S0218625X15500912

18. ASTM D2244-02. Standard Practice for Calculation of Color Tolerances and Color Differences from Instrumentally Measured Color Coordinates, American Society for Testing and Materials (ASTM). Pennsylvania. 2005: p. 13. 
19. ASTM D143-14. Standard Test Methods for Small Clear Specimens of Timber, American Society for Testing and Materials (ASTM). Philadelphia, USA. 2014: p. 8.

20. EN 205. Adhesives-Wood Adhesives for Non-Structural Applications-Determination of Tensile Shear Strength of Lap Joints. Asociación Española de Normalización y Certificación (AENOR). UNE-EN 205, British. 2003: p. 5.

21. ASTM D5266-99. Standard Practice for Estimating the Percentage of Wood Failure in Adhesive Bonded Joints, American Society for Testing and Materials (ASTM). Philadelphia, USA. 2005: p. 6.

22. ASTM D2017-81. Standard Method of Accelerated Laboratory Test of Natural Decay Resistance of Woods, American Society for Testing and Materials (ASTM). Philadelphia, USA. 2003: p. 6.

23. International Thermowood Association. Thermowood Handbook Helsinki. Finland 2003: pp. $08-04$.

24. Kocaefe, D., Poncsak, S., Doré, G., Younsi, R. Effect of Heat Treatment on The Wettability of White Ash and Soft Maple by Water Holz als Roh- und Werkstoff 66 2008: pp. $355-361$. https://doi.org/10.1007/s00107-008-0233-9

25. Kookandeh, M.G., Taghiyari, H.R., Siahposht, H. Effects of Heat Treatment and Impregnation with Zinc-Oxide Nanoparticles on Physical, Mechanical and Biological Properties of Beech Wood Wood Science and Technology 48 2014: pp. $727-736$. https://doi.org/10.1007/s00226-014-0627-2

26. Kocaefe, D., Poncsak, S., Boluk, Y. Effect of Thermal Treatment on The Chemical Composition and Mechanical Properties of Birch and Aspen BioResources 3 2008: pp. $517-537$.

27. Candelier, K., Thevenon, M.F., $\quad$ Petrissans, A., Dumarcay, S., Gerardin, P., Petrissans, M. Control of Wood Thermal Treatment and Its Effects on Decay Resistance: A Review Annals Forest Science 73 2016: pp. $571-578$.

https://doi.org/10.1007/s13595-016-0541-x

28. Straže, A., Fajdiga, G., Pervan, S., Gorišek, Ž. HygroMechanical Behavior of Thermally Treated Beech Subjected to Compression Loads Construction and Building Materials 113 (1) 2016: pp. $28-33$. https://doi.org/10.1016/j.conbuildmat.2016.03.038

29. Barnett, J.R., Bonham, V.A. Cellulose Microfibril Angle in The Cell Wall of Wood Fibres Biological Reviews 79 (2) 2004: pp. $461-472$. https://doi.org/10.1017/S1464793103006377

30. Priadi, T., Hiziroglu, S. Characterization of Heat Treated Wood Species Material and Design 49 2013: pp. $575-582$.

https://doi.org/10.1016/j.matdes.2012.12.067

31. Moya, R., Bond, B., Quesada-Pineda, H. A Review of Heartwood Properties of Tectona Grandis Trees from FastGrowth Plantations Wood Science and Technology 48 2014: pp. $411-433$. https://doi.org/10.1007/s00226-014-0618-3

32. Süleyman, K. Performance of Three Thermally Treated Tropical Wood Species Commonly Used in Turkey Industrial Crops Production 36 2012: pp. 355-362. https://doi.org/10.1016/j.indcrop.2011.10.004
33. Chen, Y., Tshabalala, M.A., Gao, J., Stark, N.M., Fan, Y. Color and Surface Chemistry Changes of Extracted Wood Flour After Heating at $120^{\circ} \mathrm{C}$ Wood Science and Technology 48 201: pp. 137-142. https://doi.org/10.1007/s00226-013-0582-3

34. Bourgois, J., Bartholin, M.C., Guyonnet, R. Thermal Treatment of Wood: Analysis of the Obtained Product Wood Science and Technology 23 (4) 1989: pp. 303-310. https://doi.org/10.1007/BF00353246

35. Yildiz, S., Tomak, E.D., Yildiz, U.C., Ustaomer, D. Effect of Artificial Weathering on The Properties of Heat Treated Wood Polymer Degradation and Stability 98 2013: pp. $1419-1427$. https://doi.org/10.1016/j.polymdegradstab.2013.05.004

36. Awoyemi, L., Jones, I.P. Anatomical Explanations for The Changes in Properties of Western Red Cedar (Thuja plicata) Wood During Heat Treatment Wood Science and Technology 45 (2) 2011: pp. 261-267. https://doi.org/10.1007/s00226-010-0315-9

37. Bal, B.C. Some Physical and Mechanical Properties of Thermally Modified Juvenile and Mature Black Pine Wood European Journal of Wood and Wood Products 72 (1) 2014: pp. $61-66$. https://doi.org/10.1007/s00107-013-0753-9

38. Spiegelberg, H.L. The Effect of Hemicelluloses on The Mechanical Properties of Individual Pulp Fibers Tappi Journal 49 1966: pp. 388-396.

39. Kocaefe, D., Poncsak, S., Tang, J., Bouazara, M. Effect of Heat Treatment on the Mechanical Properties of North American Jack Pine: Thermogravimetric Study Material Science 45 2010: pp. 681-687. https://doi.org/10.1007/s10853-009-3985-7

40. Kuzman, M.K., Kutnar, A., Ayrilmis, N., Kariz, M. Effect of Heat Treatment on Mechanical Properties of Selected Wood Joints European Journal of Wood and Wood Products 73 2015: pp. 689-691. https://doi.org/10.1007/s00107-015-0931-z

41. Kamdem, D.P., Pizzi, A., Jermannaud, A. Durability of Heat-Treated Wood Holz als Roh-und Werkstoff 60 2002: pp. $1-6$. https://doi.org/10.1007/s00107-001-0261-1

42. Venäläinen, M., Partanen, H., Harju, A. The Strength Loss Of Scots Pine Timber in An Accelerated Soil Contact Test International Biodeterioration and Biodegradation 86 2014: pp. $150-152$. https://doi.org/10.1016/j.ibiod.2013.08.006

43. Calonego, F.W., Severo, E.T., Furtado, E.L. Decay Resistance of Thermally-Modified Eucalyptus grandis wood at $140{ }^{\circ} \mathrm{C}, 160{ }^{\circ} \mathrm{C}, 180{ }^{\circ} \mathrm{C}, 200{ }^{\circ} \mathrm{C}$ and $220^{\circ} \mathrm{C}$ Bioresource Technology 101 (23) 2010: pp. 9391-9394. https://doi.org/10.1016/j.biortech.2010.06.119

44. Paul, W., Ohlmeyer, M., Leithoff, $\mathbf{H}$. Thermal Modification of OSB-Strands by A One-Step Heat PreTreatment-Influence of Temperature on Weight Loss, Hygroscopicity and Improved Fungal Resistance Holz als Roh-und Werkstoff 65 2007: pp. 57-63. https://doi.org/10.1007/s00107-006-0146-4

45. Jämsä, S., Ahola, P., Viitaniemi, P. Performance of Coated Heat-Treated Wood Part B: Coatings Transactions. Surface Coatings International 82 1999: pp. 297-300. https://doi.org/10.1007/BF02720126 